\title{
The Image of the Oriental Muslim in Lord Byron's The Giaour (1813)
}

\author{
Abdulhafeth Ali Khrisat ${ }^{1}$ \\ ${ }^{1}$ Al-Imam Mohamed Ibn Saud Islamic University, Saudi Arabia \\ Correspondence: Abdulhafeth Ali Khrisat, Department of English Language and Translation, College of \\ Languages \& Translation, Al-Imam Mohamed Ibn Saud Islamic University, P. O. Box 5701, Riyadh, 11432, \\ Saudi Arabia.
}

$\begin{aligned} & \text { Received: November 1, } 2017 \\ & \text { Accepted: August 5, } 2018 \quad \text { Online Published: August 29, } 2018 \\ & \text { doi:10.5539/ells.v8n3p59 }\end{aligned}$ URL: https://doi.org/10.5539/ells.v8n3p59

\begin{abstract}
This paper aims to examine The Giaour (1813), a significant poetic work by Lord Byron, nineteenth century romantic British poet, in terms of its presentation of Oriental characters like Hassan and his wife, Leila. Byron uses references to the Oriental Islamic practices through his portrayal of Muslims' celebration of Ramadan, call for prayer in the mosque, and allusions to the equality of women and men in the Qur'an. Byron, like other Orientalists, adopts an unfairly attitude towards the Orient. His portrait of the Oriental society as patriarchal, where the woman has no freedom at all, a prisoner, and a victim, is embodied in The Giaour's character of Leila, Hassan's wife. In brief, Lord Byron's The Giaour reveals his stereotypical Orientalist's attitude towards the Oriental society.
\end{abstract}

Keywords: Orient, Byron, The Giaour, Poetry, Romanticism, Nineteenth Century.

\section{Introduction}

Orientalism is used to reflect on the studies conducted by European writers about the Eastern culture, particularly of Muslims and Arabs. It refers to all writings produced by academics and artists who hold their interpretation of the East through the depiction of the Muslim as a biological inferior, culturally backward and displaying domination. Said (1978) uses the term "Orientalism" to describe artistic and academic Western tradition of prejudiced interpretations of Arabs and Muslims that have been shaped by the European imperialism and its attitudes in the eighteenth and nineteenth centuries; Orientalism is tied to the imperialistic societies which produced it. What has formed the Oriental image is the Anglo-French-American experience that ran for almost a thousand years (p. 17). Said is definitely accurate when he refers to Orientalism as the vast differences between the colonized Orientals and the imperialist capitalist European societies who have tried to reinforce their own superiority on the Orient. Butler (1988) remarks that the Orient has long fascinated British artists as an imaginary realm of luxury, violence, and sensuality (p. 4). Carey (1997) claims that the early cultural exchange has appeared in the English writers focus on "the potential interchangeability of self and other rather than the radical opposition between the two" (p. 34). Richardson (2002) acknowledges that after September 11, 2001 attacks on New York, the Western and American media "recirculate the old binaries" East and West, Islam and Christendom which speak to the "stereotypical Oriental Other" that provides filmic and literary representations of the Oriental culture.

\section{European Writers and the Orient}

According to Sardar (1999), despite the fact that it has academic advances, modern Orientalism proceeds to rely heavily on the medieval images of Islam: "It has only discarded old fashioned clothes in favor of modern attire." Moreover, "Oriental scholarship lacks clear thinking, objective standards and basic courtesy, tolerance and moderation towards Muslim points of view." The Orientalists attempt to make assertions which are unproven but "vague generalizations". Their scholarship is just a process of producing "speculative discourses on the obvious" (p. 58).

What nonwestern scholars are left with about the Orientals is secondary sources consisting of second hand reports of colonial administrators, accounts or reports of travelogues, reports of societies' religious missions and more importantly, literary fabrications because the methodology of Orientalism was "tainted with enthusiasm and racism in all its variant" (Abdul-Malek, 1963, p. 80).

The Orient has long fascinated the Western artists as an imaginary realm of luxury, violence, terror and sensuality. 
It is a place of pleasure, mystery and destined to be exploited by the West. The Orientalists' image of the Oriental woman is a sensual being in their imagination. Khrisat (2012) believes that the Western writers, particularly the English ones "create a tradition through distorted image of Islam as a false religion and Arabs as 'Saracens' and infidels" (p. 21). Haddad (2002) emphasizes that European poets not only do they make reputations but also a living from writing "poems on Oriental topics." These European poets think that the Orient includes an arena of "poetic experimentation and maps out an alternative aesthetic space" (p. 2).

Said (1978) argues that what has been written about the East is no more than false assumptions on which the Western attitudes towards the East were formed. The texts which were written even by the most knowledgeable Western Orientalists are highly biased, portraying the Orient as irrational, strange, weak, and primitive and feminized "Other" in comparison with the rational, civilized, strong, and masculine West: "The relationship between Occident and Orient is a relationship of power, of domination, of varying degrees of a complex hegemony" (p. 5).

Lord Charlemont, a twenty-one-year-old Irish traveler to the Ottoman Empire, wrote in 1749: "the mode of living at Constantinople is to a young man as pleasant as in any great city whatsoever" (quoted in Mansel). It seems what has attracted Charlemont was mentioned in his account of this travel. Charlemont said that homosexuality, which he abhorred, was prevalent. In his travel from Constantinople to Alexandria, Egypt, he admired an Ottoman admiral on whose ship were Christian slaves. According to Charlemont, these slaves were put under mild pressure to accept Islam, but had a small chapel aboard ship in which they were (in fact compelled) to worship. Charlemont couldn't deny religious tolerance shown by the Oriental Ottomans (History of Ireland, 2005).

\section{Byron and the Orient}

Lord Byron was interested in the Orient, particularly Islam and the East, represented by the Turks. In a letter to his mother on March 19, 1810, Byron said, "I promise to turn into Mussulman rather than return to it [his country]." (Dallas, 2011, p. 113). According to Gross (2001), Byron truly appreciates the Oriental culture. Nellist (1988) views Byron as a Western traveler going to the East and becoming an "emissary of that East back to the West" (p. 71). Melikian (1973) notes that Byron does not view the East as either exotic or inferior. Undoubtedly Byron is one of the first English writers who used the term "Orient" in 1812. Garber (1988), remarks that "... if Orientalism is, for us, an 'antiworld', Byronic Orientalism involves a pitting of self against self" (p. 82). Franklin (2007) confirms that Byron has been inspired early by Spain as a place where Christian and Islamic culture collided. Cochran (2006) thinks that cultural variety becomes hard to see and the belief in the "Eurosupremacy loses its power in this version. . . East is West and vice versa" (p. 14). However, Cochran sees a "comic potential" in the view that Occident and Orient are identical.

In a letter to Murray on March 25, 1817, Byron and Moore talked about Moore's writing of Lalla Rookh, comparing his own titles to Moore's. (Note 1)

I am very sorry that I called some of my own writings 'Tales' because I think that they are something better. Besides we have had Arabia and Hindoo, and Turkish, and Assyrian Tales. But, after all, this is frivolous in me; you won't, however, mind my nonsense. Really and truly, I want you to make a great hint, if only out of self-love, because we happen to hold cronies; and I have no doubt you will - I am sure you can (BLJ 5, pp. 186-87).

Moore tells his mother on July 22, 1813: "[Byron's] last thing, the Giaour, is very much praised, and deservedly so, indeed, I think he will dethrone Walter Scott" (Letters, 1964, I, p. 270). Byron subtitles 'The Giaour': 'A Fragment of a Turkish Tale', 'The Bride': 'A Turkish Tale' and both 'The Corsair' and 'Lara': 'Tales'.

Byron's influence isn't limited to Thomas Moore but also to other Romantic poets such as Robert Southey and others. Southey's calls and others for mass conversion of Oriental peoples was encouraged by Byron's experience of the Orientals and "Southey's sympathy" for them (Butler, 1990, p. 67). Butler explains that fictions encourage and emphasize "the supposed despotism, fraud, and cruelty of Eastern religions."

Dunville (2014) remarks that Byron's initial use of Orientalism in the 1800s connotes a type of fascination and portrayal of practices, customs and mores of the Eastern culture. Dunville believes that this term, "Orientalism", has been altered by Edward Said (1978) to refer to the vast differences between the capitalist European society, who have tried to reinforce their own superiority, and the East. Dunville concludes that "Byron's Orientalism looks to the hopeful future and Said's Orientalism looks to a tragic past." Cheeke (2003) observes that Byron's Oriental tales are bound together by a kind of "formulaic homogeneity", which reveals that the Eastern "Other" codes intercept and overlap with the British ones and influenced by both "British imperial politics and literary 
conventions" (59). In fact, the difference was, is and will be there: the Western [including the American] self stands in opposition to the Oriental 'Other.' Although many call for exchange and globalization, Europe or the West, including the Americans, views the Orient as different because it is the "Other".

Byron has been attracted to the Orient since his infancy. In the autumn of 1802, Byron has stayed with his mother for a short time at Bath. During this time, Moore (2011) mentions what has been retold to him by a young lady, Lady Riddel: "At a masquerade given by Lady Riddel, he [Byron] appeared in the character of Turkish boy, _ as sort of antiseptic, both in beauty and costume of his own young Selim" [the central character of The Bride of Abydos]" (p. 26). The Orient has always been associated with fancy and pleasure. Commenting on this matter, Eisler (1999) remarks that Byron takes special delight in this costume "because he thinks while he is wearing it, he fancies that he has become "an Oriental potentate, powerful free, to whom nothing is forbidden" (p. 223). Byron's interest in the Orient has motivated him to travel from 1809 to 1811 to the Mediterranean, visiting Greece and Albania, where he has spent some time at Ali Pasha's court. Later Byron visited Constantinople. Byron kept no journal, but Hobhouse, his companion made a full record of their travel together during this period. When Thomas Moore edited Byron's letters, he used much of Hobhouse's book to supplement Byron's account. The Orient has left a significant impact upon Byron. As a result of his direct contact with the Orient, Byron has contributed to the development of the Oriental tale in verse. After his publication of The Giaour (1813), Byron said:

Knolles-Cantemit, De Tott, Lady Montagu, Haukins's translations from Mingnot's History of the Turks the Arabian Nights, All travels or histories or books upon the East, I could meet. I had read as well as Rycaut, before I was ten years of old. I think The Arabian Nights first (quoted in Disraeli, 1834, p. 68).

Sharafuddin (1994) expresses his doubts about Byron's reading of Paul Rycaut's The Present State of the Ottoman Empire (1668) before the age of ten. Sharafuddin also refers to the fact that Rycaut has been "a sensationalist" whose observations about the Turkish society and politics were limited by his accounts of violence and sex (p. 216). However, Byron has acquaintance with Oriental rulers besides his travels to Albania and Constantinople, and has real experience with the Ottomans accompanied by his second hand knowledge on the Orient from books produced by other travelers: "I . . . have been at more Mohamometan than Christian courts" (Mansel, 2003). Byron also later recalls: "It was the first book [History of the Ottoman Empire] that gave me pleasure when a child; and I believe it had much influence on my subsequent wishes to visit the Levant, and gave, perhaps, the Oriental coloring which is observed in my poetry" (quoted in Webster, 2011). Undoubtedly Rycaut's exciting accounts and fantasies about violence and sex in the Orient has been the main, if not the only, motive for Byron's traveling.

\section{Byron, Greece and the Orient}

Boehmer (2005) emphasizes that colonial literature was "written by and for colonizing Europeans about non-European lands dominated by them. This literature was motivated by theories concerning the "superiority of European culture and the rightness of the empire" (p. 3). Said (1994) states that colonial literature has reflected opposition and decolonization: "Just as culture may predispose and actively prepare one society for the overseas domination of another; it may also prepare that society to relinquish or modify the idea of overseas domination" (p. 200).

According to Byron, the Greeks take the responsibility for the deterioration of their country and for the bad conditions of their state and of their moral deficiency; so they allow the "Oriental low-married Muslims" subjugate the virtuous classic Greeks.

'Twere long to tell, and sad to trace,

Each step from Splendour to Disgrace

Enough _ no foreign foe would quell

Thy soul, still itself

Yet! Self-abasement paired (The Giaour, II, pp. 137-42)

The portrait of the Orient as different from the European is included in Lord Byron's works. In a letter to Thomas Moore on Sept.1 1813: "The Giaour. I have added to a good deal, but still in foolish fragments." (my italics). Moore 1832, vol. II, p. 238). Obviously, the poem has been told by a number of speakers in disorder and in fragments. Most of the speakers have never been introduced so that the reader has to exert some effort in identifying the character's speech. In another letter on Sept. 8, 1813 to Moore, Byron said: "By the coash I send you a copy of that awful pamphlet 'The Giaour' which has never procured me half so high a compliment as your 
modest alarm" (II, pp. 241-42).

Writing earlier to John Murray on August 26, 1813, Byron says, "I have, but with some difficulty, not added any more to this snake of poem [The Giaour], which has been lengthening into rattles every month" (Moore, II, p. 227). Moore also remarks that Byron has adopted a series of fragments, a set of "Orient pearls at random strung" and left him free to introduce without reference to more than the general complexion of his story. Moreover, Byron has employed whatever images and sentiments of his fancy that resulted in a poem from 400 lines to nearly 1400 (vol. I, p. 390).

Byron feels sad for what has happened to Greece. Greece is now under the control of Oriental Muslim Turks' tyranny: Byron describes the Greeks as slaves to slaves [the Turks]: (the West's wrong popular view of the Islamic government in Turkey is that civil servants are the property of the Sultan):

The hearts within the valley bred

The fiery souls that might have led

The sons to deeds sublime,

Now crawl from cradle to the Grave,

Slaves nay, the bondsman of a Slave,

And Callous, save to crime (II, pp. 148-53).

\section{The Oriental Characters in Byron's The Giaour}

McGann (1993) has noted that Byron taught his public to read his eastern poetry as "much more than textually autonomous poetic fragments." In order to be acquainted with these poems, McGann asked the reader to make "elaborate referential connections, political, geographical and historical" (p. 16). Byron was enthralled by the Orient, its people and culture. Like other Orientalists, Byron had the desire to expose and explore the Orient whether through travels, translations about the East, and fabricating fantasies and leaving his imagination to sweep him away from reality.

Byron's The Giaour was first published by T. Davidson in the series of Oriental romances in 1813. In a letter to Murray on Dec. 12, 1821, Byron tells him that the "Giaour story" had "some foundations on facts" (p. 345). During his visit to the Greece in 1809-1810, Byron was introduced to the Turkish custom of killing a woman, wrapped in a sack into the sea if found guilty of adultery. The poem has been subtitled as "A Fragment of a Turkish Tale". How Byron has been introduced to this Oriental custom remains in doubt. Has the event happened during his visit to Albania or has Byron imagined this fantasy in order to create a character that embodies the Byronic hero qualities? In his conversation with Shelley's cousin, Tom Medwin, Byron told him that he had "observed a crowd of people moving down into the shore, and the arms of soldiers glittering among them." Byron's curiosity made him enquire about this procession. When he learned that these people were carrying an "unfortunate girl" wrapped in a sack to be thrown into the sea, he interfered "with the chief magistrate, backed by a heavy bribe, saved her; but only on condition that she immediately quit Athens" (quoted in Webster (2011). Byron is no different from other Orientalists or Hollywood directors and producers. The portrayal of the Western Christian hero as a savior, the most sensitive humane in the universe and who endures troubles and strives ferociously to assist the "Other" in need. This hero is a kind of Christ figure who saves the Oriental woman.

Byron has great admiration for Beckford's Vathek. In fact, Byron's attitude toward the Orient is biased like William Beckford in his Vathek, where the characters, "living their passions, connected with Oriental setting, are projections of the author's personal and cultural aspirations" (Khrisat, 2011, p. 21). In The Giaour, Byron borrows from Vathek the image of the flaming hearts:

But thou, false Infidel! Shalt writh

Beneath avenging Monkir's scyyhe;

And from its torments 'scape alone

T'wander round lost Eblis' throne'

And, fire unquenche'd unquenchable,

Around, within thy heart shall dwell (II, pp. 749-54)

Byron also has been acquainted with Thomas Hope's Anastsius (1820), a travel book describing the life of the Oriental Muslim Turks, their culture, religion, law and literature. It is reported that Byron confided to Marguerite, Countess of Blessington, that he wept bitter on reading Thomas Hope's Anastasius: "To have been the author of 
Anastasius, I would have given the two poems ["Child Harold" and "Don Juan"] which brought me to the most glory" (quoted in Memoirs of Thomas Hope, 1831, I: v).

In The Giaour, Byron draws on Islamic characters. Byron refers to Leila who is a Circassin, not a Turk like her husband, Hassan, or a Greek, like her lover, the Giaour. Byron emphasizes that Muslims oppress women and dominate them. He presents Leila as a victim, who has eloped successfully from Hassan's harem, prison, with the Giaour. Byron's presentation of Leila leaves the impression that she has been unable to speak about herself. Her position is emphasized by not allowing her to tell about what has happened; she seems to be ignored for not speaking her thoughts. Not only the Oriental patriarchal society ignores her, but Byron's speaker himself possesses the same quality and holds the same attitude toward the woman. This oppression and domination reveals that Leila has not been allowed by her husband, Hassan, and by Byron's speaker to tell about her personal feelings and express her thoughts. All what the audience know about her is from her impact on both men, Hassan and the Giaour. Byron's criticism of the Orient is also applicable to him since his speaker ignores Leila's individuality. There is violence directed toward Leila: Brinks (2010) sees the Giaour's Orientalism as a "penetrating critique of racial and heterosexual gender relations in the Christian" as well as in the Occident. Brinks also emphasizes that Byron's dramatizing "gendered divisions of power, property and law" is through "the narrative of Leila's sexual repression" and the erotic implications "extend beyond the heterosexuality of the Giaour-slave-harem-masters configuration" (p. 75).

\subsection{Leila and Hassan in The Giaour}

In The Giaour, Leila's commitment of a crime has led her husband, Hassan, to punish her. Her punishment is to be drowned after wrapping her into a sack. Hassan attempts to reestablish his dignity because he feels that Leila has made him lose this dignity. Lew (1996) argues

Western empire, in reducing or, fetishing 'harem' as merely a collection of female bodies, facilitated the symbolic representation of . . . empire building. What endangered politics. . . might experience as dismemberment could [thus] be seen through Western eyes, as 'liberation' (p. 192).

Leila enjoys all the freedom in the harem. But when Leila is wrapped into the sack, it is symbolic in the sense that Hassan has given her less space than that of the harem. For the Orientalists, the harem is meant to be a sexual place. The Oriental woman is seen as a sensual being in the Orientalist's imagination. Byron's speaker tells of Leila's beauty:

Her eyes dark charm 'twere vain to tell,

But gaze on that of the gazelle,

It will assist the fancy well;

As large, as languishly dark (II, pp. 473-76).

However, at the same time, "But soul beamed forth in every spark/ That darted from beneath the lid" (II, pp. 477-78). Byron's description of the Oriental woman is different from the woman in his culture. Leila seeks freedom to escape oppression and domination. She "breaks her bower" and goes out into the world of men taking the Giaour, a nameless Christian as a lover. Leila rebels against the values that structure the Oriental society.

Byron confirms his Orientalist's attitude toward the Orient when he has criticized Lady Mary Worthley Montague. In her letters from Constantinople, Lady Mary Montague tells of the Muslim women who have more freedom than their English counterparts. Byron accuses her of lying: in a letter to his mother dated 28 June, 1810, when Byron was in Constantinople, he has written; "by the bye, her Ladyship, as far as I can judge, has lied, but no half so much as any other woman could have done in the same situation" (Marchand, I, p. 250).

\subsection{The Orientalists and the Oriental Woman}

In the Orientalists works, the portrayal of the Oriental woman comes from their prevailing fantasies and exoticism which they have drawn from the European female travelers whose authenticity remains questionable. These representations of the female travelers are products in which they have attempted to give a deformed image of the 'Other'. These accounts narrated by both males and females have been used as the bases for many artists who have produced their paintings, which focus on the beautified nude, odalisques, lying down on a divan or engaged in overtly sexual scenes as 'dancer for all male audience in a state of undress and utter absurd on as in the paintings of Jean-Leon Gerome. The French Gerome was influenced by Levi: Very rare artists such as Lord Leighton who produced paintings of Oriental women in "Fully clothed respectability . . . suggesting a moral healthiness to go with their natural good looks." (Note 2) Other artists such as the British John Frederick Lewis who has spent such a long time in Ottoman cities and never been acquainted with Oriental women he 
produced.

According to Pardoe (1836), even women writers and those women who have attempted to give a 'fair' evaluation of the Oriental woman emphasize the continued "Otherness" of the Orient: "Women . . . their limited range of ideas . . . quiet, care less, indolent happiness ... [amusement] with trifles, careless of all sure the passing hour; a woman in person, but a child in heart" (p. 71). Herath (2015) argues that the European misconception is present in both male and female Orientalist. Herath points to the ignorance of these European women travelers in their portrayal of the Oriental women (p. 35), referring to Harvey's (2006) representation of "Men who live only with other men, become rough, selfish, and coarse; whilst women, who entirely limited to the consummation of their own sex, grow indolent, narrow-minded, and scandal loving" (p. 141).

\subsection{The Oriental Woman in Byron's The Giaour}

Like other European Oreintalists, Byron's view of the Oriental woman is that she is considered as a sex object for the pleasure of the man.

Oh! Who young Leila! glance could read

And keep that portion of his creed

Which saith that women is but dust,

A soulless toy for the tyrant's lust? (II, pp. 487-90).

The speaker's image of the woman as a "soulless toy" indicates that she is just a toy for entertaining the man. Byron himself comments on this in a note saying that this idea is a vulgar error because "The Koran allots at least a third of its paradise to well-behaved women; but for the greater number of Mussluman interpret of their own ways, and exclude their moieties from human" (McGann,1981, vol. III, p. 4.19). In a letter to Francis Hodgson on Sept. 3, 1811, on his return from the East, Byron writes: "I will bring you ten Mussulmans [who] shall shame you in all goodwill towards men, prayer to God, and duty to their neighbors" (Marchland, II, p. 89).

\section{Byron and Oriental Muslims in The Giaour}

Undoubtedly Byron is acquainted with significant Muslim practices. From The Giaour and its notes, Byron informs his readers about the Muslim qualities of virtue and hospitality: "I need hardly observe, that Charity and Hospitality are the first duties enjoined by Mahomet; and to say truth, very generally practiced by his disciples" (The Poems and Plays of Lord Byron, II, p. 46). Cochran (2006) believes that Byron's The Giaour is told from an Islamic viewpoint in part where Byron becomes the master of "Moslem's perspective" and enters into his spirit. For Cochran, Byron knows that the Giaour's killing of Hassan is a destruction of Islamic virtue while Byron has had a personal experience. But in fact, Byron holds a low opinion of the Oriental Muslims.

In another note on The Giaour, Byron writes: "Green is the privileged color of the prophet's numerous pretended descendants, with them, as here, faith (the family inheritance) is supposed to supersede the necessity of good works: they are the worst of an indifferent brood" (II, p. 136). Byron's speaker refers to the Muslim's call for prayer in the mosque: "The mosque's high lamps are quivering still/ Though too remote for sound to wake" (II, pp. 225-26). Byron also remarks that Leila has eloped on the last day of Ramadan: "Upon that eve she fled away/ When Ramazan's last sun was set." (pp. 448-49). Leila's elopement with the Giaour results in her murder. The Giaour considers Hassan's murder of Leila as being treacherous to Hassan, but it is truth and faithfulness for him. The Oriental Hassan considers her act differently from the Giaour. The Christian Western character of the Giaour stands in opposition to the Oriental Muslim Hassan. Byron's The Giaour aims to emphasize the conflict between the democratic West and the despotic Orient. Hassan murders Leila because of her treachery to him and the Giaour kills Hassan because of Leila's faithfulness to him .

Yet did he but what I had done

Had she been false to more than one?

Faithless to him, he gave the blow;

Use ghastly whiteness aids its gloom. But true to me, I laid him low (II, pp. 1118-23)

Byron doesn't appreciate the Oriental religion; in his poem on October 9, 1806, “To Eliza”, Elzbeth Pigot, his friend and neighbor, Byron directs his attack on Muslims.

What fools are the Mussulmen sect

Who to woman deny the soul; future existence

Could they see thee Eliza, they'd own their defects 
And this doctrine would meet with grand resistance

Had their prophet possess's half atom of sense

He never would have woman from paradise driven;

Instead houries, a flimsy pretense,

With woman alone he had peopled his heaven

Byron's attack on the Oriental religion of Islam allows him to throw a judgment on the Muslims by calling them "fools" and criticized the Prophet who preached the message of Islam. In another incident, Byron shows a different attitude toward the Orient. In a letter to John Murray, Byron says:

Did you look out? Is it Medina or Mecca that contains the holy sepulture? don't make me blaspheme by your negligence _ I have no book of reference or I would save you the trouble. I blush as a good Mussulman to have confused the point (Marchland, III, p. 191).

Byron seems unable to endure Murray's prejudices. Murray cast doubt on the link between Muslims and Christians. Byron tells Murray in another letter: "I send you a note for the ignorant, but I really wonder at finding among them _ I don't care one lump of Sugar for my poetry _ but for my costume, and my correctness on those points (of which I think the funeral was a proof) I will combat lustily" (p. 165).

\subsection{The Giaour in Byron's The Giaour}

Byron exaggerates in his description of the Giaour's qualities. The Giaour is seen far away cliff and "a demon of the night" (p. 11). A description of his facial expression is presented here.

He stood some dread on his face-

Soon hatred settled in its place-

It rose not with the reddening flush,

Of transient Anger's hasty blush,

But pales as unable o'er the tomb

The Giaour says about himself that he is a kind of superhuman; he doesn't feel like any other human being: in this context, the Giaour seems to be a Greek lover where he is located between humans on earth and Gods on the Olympics. His love is different from others as well as his suffering :

The Cold in clime are cold in blood,

This love can scarce deserve the name;

But mine was like lava flood

That boils in Etna's breast of flame (II, pp. 1195-98).

This comparison is between two cultures. Dimmock (2005) sees that the Anglo-Ottoman relationship is viewed with suspicion by the Catholic Europe, although it has reached its peak in the mid-1590s; the Europeans see the 'new Turkes' not Ottoman Muslims but 'English protestants' as they view the ritual and devotional similarities between England's reformed church and Islam.

For Byron, there are two men; a Western Christian and an Oriental Muslim. The Giaour compares his love with Hassan's. According to the speaker, the Muslims are cold in blood and their love doesn't deserve the name whereas the Giaour's is "like a lava flood" that is boiling in "Etna's breast of flame." The Giaour is determined to obtain Leila. For him, Leila is the "cherished madness of my heart" (I, p. 1187). The Giaour tells his father that he has seen her after her death: "I saw her; yes, she lived again" (I, p. 1368). In his hallucination, the Giaour holds her in his arms but he knows that is false; however, Leila "couldn't die" (I, p. 1396). The Giaour's action has left an impact on his physical appearance as well as spiritual soul.

But in that instant, o'er his soul

Winters of memory seemed to roll,

A life of pain, an age of crime,

O'er him who loves, or hates or fears,

Such moment pours the grief of years

Byron's portrait of the Giaour is mythological. As it is mentioned before, the Giaour sees himself of higher status 
than humans. Therefore, humans are unable to understand the Giaour. His action isn't welcome by the people. In fact, the Giaour feels regret because he is the reason that has caused Leila's death; however, he seems to regret nothing, saying that he would do it all again.

No_reft of all, yet undismayed

But for the thought of Leila slain,

Give me the pleasure with pain,

So would I live and love again (II, pp. 1113-16).

The Giaour represents the Christian knight who goes to fight the Muslim Hassan because of Hassan's drowning of Leila. A question may be raised: what is the relation between The Giaour and Leila and how does Leila leave an impact on the Giaour? It is Leila's gaze that arouses a love that "lift [s] from earth our low desire" while "Heaven itself descends to love" (II, p. 1134, 1136). The Giaour himself has an evil eye that possesses a cursed gaze: he is recognized by it .

'Tis he! 'tis he! I know him now;

I know him by the evil eye.

That aids his envious treachery (II, pp. 610-12).

Byron thinks that the evil eye is "a common superstition in the Levant," but those who have conceived themselves to be affected have their own singular imagining effect (McGann, III, p. 419.) The Giaour says that he wants no inspiration on his headstone as to be more quickly forgotten.

In the narration of his tale, the Giaour also tells the monk that he feels the sorrows but thanks him for listening and giving attention. Then, the Giaour asks the monk not to bury him and keep a cross above his head, without carrying a name or any kind of emblem. The Giaour's grave should be anonymous so that he will be a stranger and unknown for all those passers-by.

Then lay me with the humblest dead,

And, save the cross above my head,

Be neither name nor emblem spread,

By prying stranger to be read,

Or stay passing pilgrims tread' (II, pp. 1419-24).

\subsection{Hassan vs. The Giaour}

Hassan recognizes the Giaour by his "evil eye". Therefore, Hassan leads the battle riding his horse toward his enemy whose fiery eyes and furious word has been accompanied with a frown. In this situation, Byron attempts to make a comment through the speaker in the poem. Byron's attitude toward the Orient, particularly Muslims, is unfair. In a way of putting words out of their context, Byron remarks that Hassan calls Allah and the Prophet for help, but his words are unheard and he receives no assistance with his confrontation with the Giaour.

He called the Prophet, but his power

Was vain against the vengeful Giaour.

He called on Allah - but the word

Arose unheaded or unheard (II, pp. 679-82).

In Islam, Muslims call for help from Allah [God] if they are in distress or in a difficult situation. It isn't necessarily that these prayers are fulfilled. Allah may fulfill their hope or not.

Byron's portrayal of Hassan reveals that Byron builds up on the difference between the Orient and the Westerner. Hassan, the Oriental Muslim, couldn't stand against the Giaour, the Orientalist Christian: it is to his credit that the Giaour isn't an Oriental character: "Yet seems he not of Othman race/ But only Christian in his face" (II, pp. 810-11). Although the Giaour's character referred to as non-Christian but in fact he has gone to take refuge in the monastery and he was allowed into the religious home. Again Hassan's calls for help from Allah and the Prophet are in vain and without response, when the Giaour attacks him and watches him dying.

One cry to Mahomet for aid,

One prayer to Allah he made;

He knew and crossed me in the fray 
And watched his spirit ebb away. (II, pp. 1178-82).

In another episode, the fisherman, who watches the Giaour riding his noble stead on the beach, keeps looking at him and sees the spirit of evil. There are two characters that embody two different cultures. There is a conflict between the two; Hassan, representing the "Other" and the Giaour, representing the "Self". The Giaour's attitude is clearly stated by the speaker: "Right well, I view thee and deem thee and/ whom Othman's sons should slay or shun" (11. 98-9). Moreover, Byron's speaker remarks that the Orient feels a sense of loathsome towards the Westerner and the whole race of the Westerners. Therefore, the idea of meeting between the two characters is unlikely to happen: "I know thee not, I loathe thy race" (I, p. 91). The speaker believes that the Giaour, an enemy of the "Othman's sons", is a "daemon of the night" who vanished .

Byron attributes negative features to the Oriental character. After the Giaour's ambush of Hassan, a Muslim speaker contemplates Hassan's tomb.

There sleeps at Mecca but the knees as true as Osmanlie

As e'er at Mecca but the knee;

As ever scorned forbidden wine,

Or prayed with face towards the shrine,

$\cdots$

Yet did he by a stranger's hand,

And stranger in his native land;

And unavenged, at least, in blood. (II, pp. 729-32, 735-37).

Byron describes Hasan's grave after many years have passed on that neglected graveyard.

A turban carv'd in coarsest stone,

A pillar with rank weeds o'ergrown,

Whereon can now be scarcely read

The Koran verse that mourns the dead;

Point out the spot where Hassan fell

A victim in that lonely fell.

There sleeps as true an Osmanlie

As e'er at Mecca bent the knee;

As ever scorn'd forbidden wine,

Or pray'd with face towards the shrine,

In prisons resumed anew

At solemn sound of 'Alla Hu!' (II, pp. 723-34).

In his notes to this passage, Byron writes, "The turban _ pillar _ and inscriptive verse from the Koran decorate the tomb of the Osmanlies, whether in cemetery or the wilderness. In the mountains you frequently pass similar mementos; and on inquiring you are informed that they record some victim of rebellion, plunder, or revenge" (McGann, III: 420). Elsewhere, Byron remarks that "a turban is carved in stone above the graves of men only" (424). In Islamic culture, the dead body's head is laid towards Mecca. In his note about the "solemn sound of "Alla Hu", Byron says that the "Alla Hu" are "the concluding words of the Muezzin's call to prayer from the highest gallery on the exterior of the Minerat" (420). In all these notes and details, Byron proves to be acquainted with many aspects of the Orient.

According to Byron, Hassan is superstitious and childish, since he believes in superstitions and thinks that the Giaour becomes a vampire, taking the life of his family and the lovely ones by sucking their blood.

But first thy daughter, sister, wife/

Thy corpse shall from its tomb to be rent;

The ghastly haunt thy native place,

And suck the blood of all the race (II, pp. 755-58). 
Byron views Hassan, the Orient, as one who believes that the Giaour will prey and feed on his descendants after his death. In other words, Hassan is fictitious and superficial; he convinces himself that the Giaour is resurrected from his death. Although Hassan is dead and his hand is cut off and lies mutilated by the Giaour, he can still inflict pain upon his competitor by cursing the Giaour through his "unclosed eye."

His back to earth, his face to heaven,

Fall'n Hassan - lies - his unclos'd eye

Yet lowering on his enemy,

As if the hour that seal' $d$ his fate

Surviving left his quenchless late (II, pp. 668-72).

As a result, the Giaour has been infected from Hassan with a gaze that is filled with evil suffering, so that the friar to whom the Giaour confesses is disturbed.

The flash of that debilitating eye

Reveals too much of times gone by

Which speaks, itself unspeakable,

For in it lurks that nameless spell (pp. 834-37).

\section{Conclusion}

Like other Orientalists, Byron presents a distorted image of the Orient and its culture, particularly the Muslim Turks. The Orient is described as barbarous and patriarchal dominating women and treating them as sex objects; in the incident of Hassan and Leila, the Giaour, representing the Christian Western hero's culture, punished Hassan, embodying Muslim Oriental culture. The poem reveals the contradiction between the two cultures and the idea of coming into harmony seems unlikely since the Orientalist has preconceptions about the Orient. What we are passing through these days of the stereotypical Oriental images supports the nineteenth century academic and imaginative demonology of the "mysterious Orient" (Ashcroft, Griffiths and Fiffin, 1989, p. 26). The Oriental terrorist image which dominates the Western media today is the best example of the developing stereotypical image fabricated by the Orientalists.

\section{Acknowledgement}

The researcher would like to thank the Deanship of Scientific Research at Al-Imam Mohamed Ibn Saud Islamic University, Riyadh, Saudi Arabia for their funding of this research no. 370704 in H.1438/2017.

\section{References}

Ashcroft, B., Griffiths, G., \& Tiffin, H. (1989). The Empire Writers Back: Theory and Practice in Postcolonial Literatures. London \& New York: Routledge.

Beatty, B., \& Newey, V. (Eds.). (1988). Byron and the Limits of Fiction. Liverpool: Liverpool UP.

Boehmer, E. (2005). Colonial and Postcolonial Literature. Oxford: Oxford UP.

Brinks, E. (2010). Gothic Masculinity: Effeminacy and the Supernatural in English and German Romanticism. Cranbury: Associated University Press.

Butler, M. (1988). The Orientalism of Byron's “Giaour”. In B. Beatty \& V. Newey (Eds.), Byron and the Limits of Fiction (pp. 87-96). Liverpool: Liverpool UP.

Butler, M. (1990). Byron and the Empire in the East. In R. Andrew (Ed.), Byron: Augustan and Romantic (pp. 63-81). New York: St. Martin's. https://doi.org/10.1007/978-1-349-21060-2_4

Byron, L. G. G. (1910). The Poems and Plays of Lord Byron. London: G.M. Dent \& Sons.

Byron, L. G. G. (2006). The Giaour. New York: Objective Systems Pty. Ltd.

Carey, D. (1987). Questioning Incommensurability in Early Modern Cultural Exchange. Common Knowledge, (6), 32-50.

Cheeke, S. (2003). Byron and Place: History, Translation, Nostalgia. Basingstok McMillan.

Cochran, P. (Ed.). (2006). Byron and Orientalism. Newcastle: Cambridge Scholars Press.

Dallas, R. C. (Ed.). (2011). Correspondence of Lord Byron (vol. I). New York: Cambridge University Press.

Dimmock, R. C. (2005). New Turkes: Dramatizing Island and Ottomans in Early Modern England. London: 
Ashgate Publishing Ltd. of Lord Byron.

Disraeli, I. (1834). Literary Characters (5th ed.). London: Edward Mokon.

Dunville, J. (2014). Romantic Politics. Retrieved http://www.web.uk.edu/-gerard/romanticpolitics/orientallism.html

Eisler, B. (1999). Byron: Child of Passion, Fool of Fame. New York: Knopf.

Franklin, C. (2007). Byron. New York: Routledge.

Garber, F. (1988). Self, Text, and Romantic Irony: The Example of Byron. Princeton: Princeton University Press.

Gross, J. D. (2001). Byron: The Exotic Liberal. Oxford: Rowman and Little field.

Haddad, E. A. (2002). Oriental Politics: The Islam in Middle East in the $19^{\text {th }}$ Century English and French Poetry. Burlington: Ashgate Publishing Ltd.

Harvey, A. J. (2006). Turkish Harems at Circassian Home in Gender, Modernity, and Liberty. Eds. Nancy Micklewright \& Reina Lewis. London: I. B. Tauris, 101-109.

Herath, T. (2015). Women and Orientalism: 19th century Representations of the Harem by European female travellers and Ottoman women. Constellations. 7(1), 31-46. Retrieved from https://journals.library.ualberta.ca/constellations/index.php/constellations/article/view/27054

History of Ireland. (2005). Charlemont on the Grand Tour. $18^{\text {th }}-19^{\text {th }}$ Century History Features 13, 2 (Mar/Apr.) Retrieved from www.historyireland.com/18th-19th-century-history/charlemont-on-grandtour/

Khrisat, A. (2011). Experience, Fantasy, and Reality in William Beckford's Vathek. Damascus University Journal, 27(3+4), 187-206.

Khrisat, A. (2012). The Image of the Orient in Samuel Johnson's Rasselas (1759). Research on Humanities and Social Sciences, 2(5), 20-27.

Lew, J. (1996). The Necessary Orientalist? Its Genre and Nineteenth Century Impressionist Misogyny in Romantics, Race and Imperial Culture. Eds. A. Richardson and J. Hofkosh. Bloomington, Indiana: Indiana University Press, 173-202.

Lewis, R. (2008). Women Orientalist Artists: Diversity, Ethnography, Interpretation. Women: A Cultural Review, 6(1), 91-100.

Mansel, P. (2003). A Lecture Given to the Byron Society. House of Lords, London.

Marchard, L. A. (Ed.). (1974). Byron's Letters and Journals. 12 vols. London: John Murray.

McGann, J. (1993). Beyond and the Truth of Masqerade. Reading Byron Essays: Selected from the Hofstra University's Byron Bicentennial Conference. Eds. A. Levine and R. N. Keane. New York: Garland, 1-19.

McGann, J. (Ed.). (1981). Lord Byron: The Poetical Works. 4 vols. London: Oxford University Press.

Melikian, A. (1973). Byron and East. Beirut: American University of Beirut Press.

Memoirs of the Life of Thomas Hope by V.R. in Anastasius, or Memoirs of a Greek Written at the Close of the Eighteenth Century. (1931). 2 vols. Paris: Baudry's Foreign Library.

Moore, T. (1964). The Letters. Ed. Wilfred S. Dowden, 2 vols. Oxford: Oxford UP.

Moore, T. (Ed.). (2011). Letters and Journals of Lord Byron: Complete in One Volume. Charleston: Nabu Press.

Moore. T. (1932). The Works of Lord Byron with Letters and Journals and his Life. 14 vols. London: Spottisewoods.

Nellist, B. (1988). Lyric Presence in Byron Turkish Tales to Don Juan in Byron and the Limits of Fiction. Eds. B. Bernard and V. Newey. Liverpool: Liverpool University Press.

Pardoe, J. (1836). The City of the Sultan and the Domestic Manner of the Turkish in 1836. In M. Wright \& R. Lewis (2006 Eds.), Gender, Masculinity and Liberty (pp. 65-76). London.

Richardson, A. (Ed.). (2002). Three Oriental Tales. Boston: New Riverside Edition.

Said, E. (1978). Orientalism. New York: Vintage Books.

Said, E. (1994). Culture and Imperialism. New York: Vintage.

Said, E. (1998). Islam through Western Eyes. The Nation. January 2, 1998. Retrieved from https://www.thenation.com/article/islam-through-western-eyes/ 
Sardar, Z. (1999). Orientalism. London: McGraw Hill.

Sharafuddin, M. (1994). Islam and Romantic Orientalism. London: I.B. Tauris Publishers.

The Poems and Plays of Lord Byron, vol. II. (1910). London: J. M. Dent \& Sons.

Vail, J. W. (2001). The Literary Rethinking of Lord Byron and Thomas Moore. Baltimore and London: Johns Hopkins UP.

Webster, J. (2011). Byron and Islam. Retrieved from www.pathfinderaudio.co.uk/bronismislam.html

\section{Notes}

Note 1. On Byron and Moore's discussion about the Orient, see Vail (2001).

Note 2. See Lewis (2008), pp. 91-106, see also Pardoe (2006), pp. 65-76.

\section{Copyrights}

Copyright for this article is retained by the author, with first publication rights granted to the journal.

This is an open-access article distributed under the terms and conditions of the Creative Commons Attribution license (http://creativecommons.org/licenses/by/4.0/). 